Chapter 11

\title{
Urban unrest and non-religious radicalization in Saudi Arabia \\ Pascal Ménoret
}

And that union, to attain which the burghers of the
Middle Ages, with their miserable highways,
required centuries, the modern proletarians,
thanks to the railway, achieve in a few years.
Karl Marx
The road that crosses the market is very broad;
loaded caravans can pass through it.
Anonymous, Nejd, nineteenth century AD

The expressions of dissent in contemporary Saudi Arabia, whether through violent action or ideological and theological constructions, are well documented today. Recent studies have provided valuable information on bombings and incidents between armed groups and the security forces (Cordesman and Obaid 2005). Both the various Salafi discourses that sustain consent to or protest against the Saudi state and the different Islamic movements have also been studied (Al-Rasheed 2007). The very contexts within which violence appears and develops are less well known. It is often said that these contexts are linked with various levels of state violence, the repression of political activities, and the preservation of a status quo through several means of controlling the public sphere. This formula is correct. It grasps the heavy role played by specifically political repression in the radicalization of a whole range of activists who might otherwise have chosen other - more peaceful - means of expression had the circumstances been different. Yet such a way of writing the history of radicalization does not say anything about the thousands of Saudis who do not participate in violent activism or intellectual and political dissent. These ordinary people are often referred to as a 'silent majority'. It remains to be seen whether this silence is due to apathy and inaction or to the fact that such ordinary Saudis, in their effort to channel their discomfort with the system as a whole, use repertoires and dictionaries that do not fall into the Islamic category. It is essential to read and analyse the Islamic discourses and to observe and interpret the history of Islamic activism in Saudi Arabia. Such an elitist focus may nevertheless overlook more discrete events that might explain, more efficiently than the grand narrative of protest, mobilization, repression, and radicalization, the way ordinary 
people refer to state violence and try to cope with its manifestations on a day-to-day basis.

The people we will be discussing are young and marginalized male bedouins. They are neither Islamic activists nor intellectuals. They are not totally disenfranchised, although they come from fragile social milieus. Nor are they the most marginalized people in Saudi Arabia, for they live in modern neighbourhoods of the capital, Riyadh, and can at least proudly refer to their tribal heritage. If they have experienced state oppression, it was inside neighbourhood police stations, not in political prisons, and the crimes they were charged with were more linked to petty robbery and violation of driving regulations than with political dissent. Like young women, they are the first target of various disciplinary institutions, such as the regular police forces, the religious police or Committee for the Promotion of Virtue and Prohibition of Vice (Hay'at al-Amr bi-IMa'rûf wa-n-Nahi 'an al-Munkar), and the innumerable private security companies that tend to enforce a strict social and gender segregation. Yet these young men's activities can only superficially be described as mere juvenile delinquency. In their own way, they challenge state authority and the official practices that depoliticize the daily activities of ordinary Saudis. They are both a result of de-politicization and a challenge to it. In other words, we are here going to work on what some may call 'sub-political' phenomena, which deserve in our purview an authentic political analysis. Delinquency, petty robbery, and multiple violations of common rules and regulations have often been overlooked or despised by political science.

\footnotetext{
Prevailing definitions, by stressing articulated social change goals as the defining feature of social movements, have had the effect of denying political meaning to many forms of protest. ... The effect of equating movements with movement organizations - and thus requiring that protests have a leader, a constitution, a legislative program, or at least a banner before they are recognized as such - is to divert attention from many forms of political unrest and to consign them by definition to the more shadowy realms of social problems and deviant behaviour. (Piven and Cloward 1977: 4-5)
}

The apostles of the official Saudi status quo themselves tend to see all forms of protestation - from everyday resistance to public demonstration and to terrorism - as mere social or ideological diseases to be cured by appropriate methods of prevention and repression. By widening the scope of political analysis, we hope to more efficiently grasp the nature of an authoritarian public space where, beyond 'the policeman, the landlord or the "people of worth" ... every gesture of revolt proves to be impossible, since the real goal is still unreachable' (Farge 1979: 151).

\section{Tafhit, from oppositional style to 'street terrorism'}

Among the 'thousands ways of defying authority, from gibes to sneaky farces and from throwing of excrement to insults and beatings' (Farges 1979: 151), we would like to focus on a truly contemporary way of resisting marginalization and social racism, an 
authentic 'street culture of resistance' which is 'not a coherent, conscious universe of political opposition but, rather, a spontaneous set of rebellious practices that in the long term have emerged as an oppositional style' (Bourgois 1996: 8). This particular street culture is called tafhit or hajwala1 by its aficionados, mainly adolescents and young men living in the peripheral neighbourhoods of Riyadh. Its purpose is 'jumping traffic lights, speeding like crazy, losing the police, slaloming between cars,' and doing acrobatic skids at top speed, usually above $200 \mathrm{kmph}$. The technical goal of tafhit is to execute extremely dangerous figures that might be fatal for both the drivers (who are called mufahhats, in reference to tafhit) and their fans (the mushajji 'in or jumhur). The most famous of these figures are the natla (lateral skid), the 'ugda (looping), and the istifham or 'question mark' (U-turn at top speed). They might be executed alone or within series, the most widespread being the combination natla-'ugda.

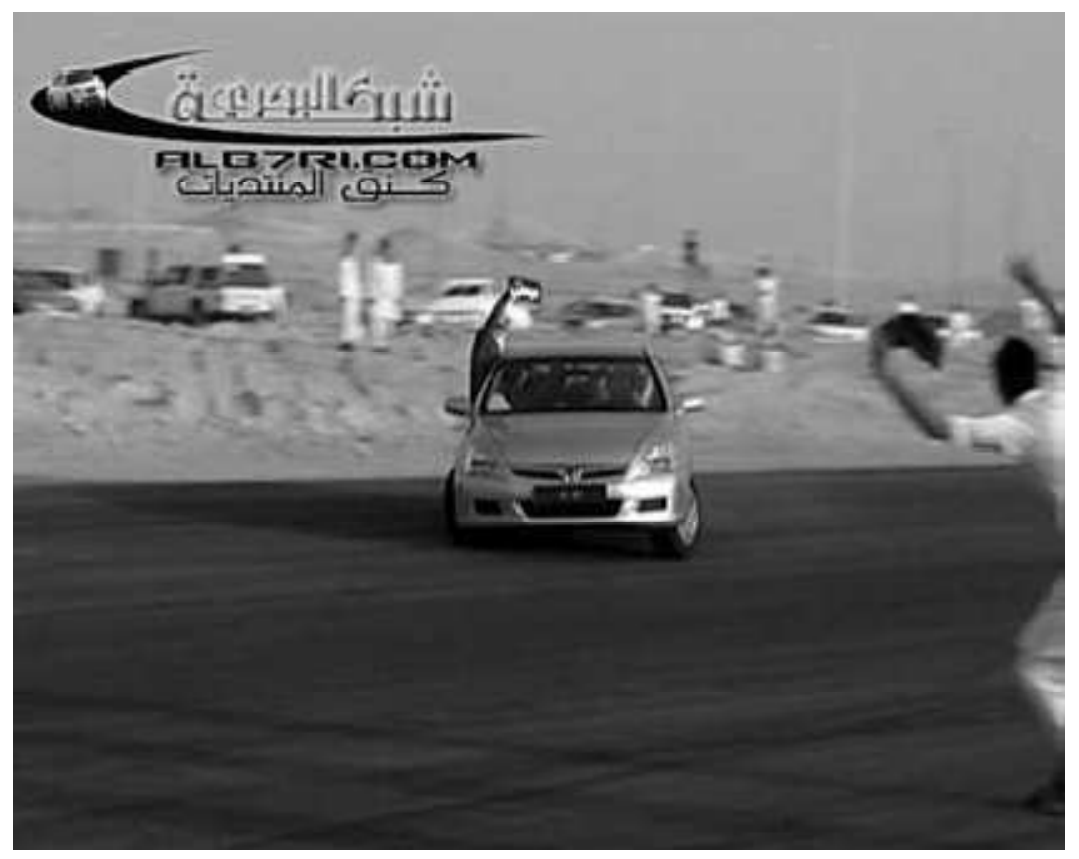

Fig. 1: Street heroes. The mufahhat is executing a natla while one of his attendants waves his logo in direction of the overwhelmed public. (Source: www.alb7ri.com)

The social goal hajwala represents is, for every 'skidder', to please his public and become the hero of the day. This can express through various means: by doing tafhit, the skidder accumulates social capital (he widens his social networks), economic capital (through the donations he receives from well-off young fans or the advertisements he makes for tafhit websites), and, above all, symbolic capital and public respect: senior skidders, such as Bubu, al-Mustashar (the councillor), al-King, al-Khuffash (the bat), or Hitler are as famous amongst youth as international soccer players - or the main figures of the Saudi Islamic movement. In this last sense, 'speeding like crazy' and 'slaloming between cars', sometimes at one's life's expense, is a 'behaviour that appears irrationally violent, 
"barbaric", and ultimately self-destructive to the outsider' but can be reinterpreted, according to the street culture and the underground economy of symbolic exchange, 'as judicious public relations and long-term investment in one's "human capital development"' (Bourgois 1996: 24).

This highly visible practice is the gathering point of many deviances and forms of delinquency, the first of which is car robbery (the vehicles skidders play with are mainly stolen ones), followed by drug traffic and use (heroin during the 1980s and now hashish and stimulants), alcohol consumption (locally distilled grape alcohol), paedophilia, and homosexual rape. These last practices are perhaps the most emblematic of tafhit: in this strictly segregated society, the 'love of younger boys' (wir'anjiyya) is both a compensation for the invisibility of girls and women and a mode of socialization amongst youth.

The stigmatization - and criminalization in the Saudi context - of skidders as deviant homosexuals is nevertheless assumed by the tafhit fans, who recognize blatantly that the social capital they are in search of is first and foremost beautiful boys (wir', pl. wir'an). 'Alas! Our love for you [boys] is a sin!' reads a famous slogan, while anonymous street poetry celebrates wir'anjiyya as the first purpose of tafhit, far ahead of the obvious pleasure of defying police and 'jumping traffic lights'.

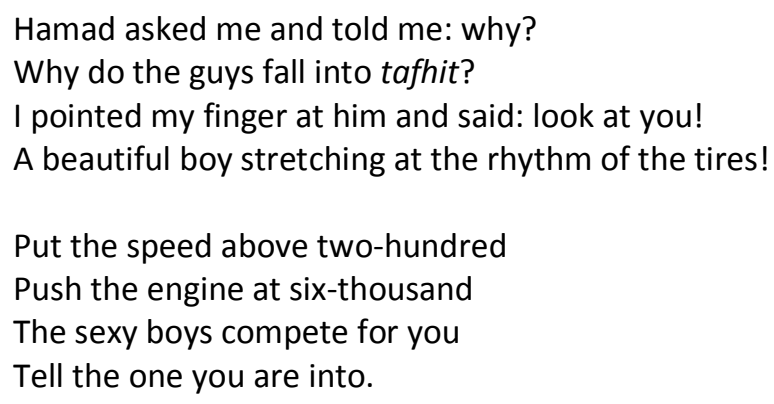

As a result of these deviances and the very many traffic accidents tafhit causes - when a poorly mastered skid ends up among the public, heavy losses are most probable hajwala has been unanimously stigmatized and criminalized by the official institutions. The police are recruiting informers in order to catch the new trends and follow up the main wanted skidders, while the media, the research centres and various Islamic institutions have targeted tafhit as both an object of analysis and the goal of many prevention and awareness campaigns. One good example of the way public institutions view tafhit can be provided by a documentary shown in December 2006 on national TV channel al-Ikhbariyya. Its director interviewed detained skidders inside police stations under the vigilant gaze of policemen and inspectors, an objectionable bias that tends to diffuse through the public space the repressive spirit of the police and mabahith's (the secret service) methods. The very title of the film, al-Jarimat al-murakkaba (The Composite Crime), leaves no space for questioning the social, economic, cultural, or political background of tafhit's fans: besides the terrified interviewed youngsters, the only witnesses the director has called in are a senior police officer and a professor of psychology. Tafhit is called 'street terrorism' (irhab ash-shawari') in the film, and has 
been analysed through the very categories (individual deviance and madness) state propaganda uses against Islamic activism. The social sciences departments also rely on police willingness to provide jailed interviewees in order to analyse tafhit. The same methods are indeed implemented by researchers and students, and unsurprisingly lead to the same conclusions, i.e. the identification of street rebellion with mere idiosyncratic troubles and psychological disorders (as-Sayf 1996).

On the other hand, through the 'cultural redefinition' and 'oppositional celebration' of their bad deeds 'as badges of pride' (Bourgois 1996: 130), mufahhats tend to glorify the fear they inspire in governmental institutions. The fascination for the local branch of al-Qaeda and for the Iraqi resistance naturally plays a role in this self-glorification as true 'terrorists', as made clear by the following poem:

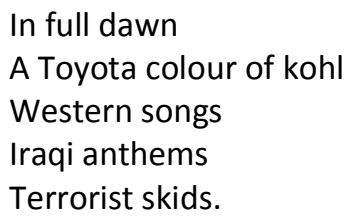

Tafhit fans are less at ease when it comes to the Islamic institutions that deal with them. Far from being bold and provocative, their reaction to them is a blend of the respect due to the social prestige of the preachers, of the sinner's self-contempt, and of dull hatred and boredom. In East Harlem, Philippe Bourgois observed 'the profound moral - even righteous - contradictory code of street ethic that equates any kind of drug use with the works of the devil, even if almost everybody on the street is busy sniffing, smoking, shooting, or selling' (Bourgois 1996: 41). Hajwala fans 'know that tafhit is bad' and that 'the end of tafhit is either death or repentance'. Their very Islamic way of putting things is somewhat unexpected, especially when it comes from young guys who occasionally use drugs or rape minors. But it is a product of both 'street ethics' and of the aggressive campaigns Islamic institutions wage against them. Preaching groups and Islamic circles are indeed the only official institutions to fight tafhit on its very battleground. As well as tafhit fans, the preachers have adopted very effective means of communication (films, clips, internet or Bluetooth), and sometimes hire rehabilitated skidders (ta'ibun) to gather young people and 'save their souls and bodies'. Yet the Islamic way of dealing with tafhit is an exception, for all other institutions have adopted a much more repressive stance towards its perpetrators. These various discourses on deviance and delinquency shall nevertheless not monopolize the observer's attention. As many speeches and narratives produced in the Saudi public sphere, they tend to replace and mime genuine action or effective policy making. Certain sociologists stress that police repression, more than being an organized campaign, is in reality a random enterprise that accommodates the phenomenon and mostly tolerates it. The criminalization of tafhit in official discourse cannot hide the loose practices of repression and the continual hesitancy of policemen, uncertain whether tafhit is a crime that deserves prison or a simple violation of the traffic regulations. Most neighbourhoods 
are poorly monitored by police forces that frequently refuse to intervene when tafhit occurs, sometimes provoking the indignation of well-intentioned fathers: having called the police because a skidder was disturbing the whole neighbourhood, one of them heard the officer on duty replying: 'Let him skid until he crashes and dies' ('Khallah yifahhat ilen yasdum wa yimut').

\section{Fighting marginalization in Riyadh}

Young skidders and their fans are mostly young bedouin men from 15 to 30 years of age. They come from vulnerable sectors of the world of urban bedouins, namely families that have recently emigrated from the countryside to the capital or, worse, split-up families living between some isolated village (ad-dira), where parents and younger children make a living out of agricultural activity, and the big town, where older sons try to cope with their studies - or give up and end up looking for ill-paid jobs. These individuals and their families live in what one may call the 'bedouin belt', i.e. the neighbourhoods that, from al-Khalij to Nazhim, Nassim and ad-Dakhl al-mahdud, surround Riyadh from the north-east to the south-west near the industrial zones and the huge compound of the National Guard. These families' social capital is scarce and limited to relations with the extended family, without any connection to the outside world of other bedouins or sedentary Riyadh townspeople. The family heads rely mainly on odd jobs in the public sector as soldiers or small-scale contractors for the army or the Ministry of the Interior; in a majority of cases, however, they are retired people, and the linguistic and cultural gap between 70 - or 80 -year-old fathers and their 20-or-so-year-old sons is huge.

Tafhit heroes tend to belong to the very families that never appear on official records: aged and retired fathers are sometimes married four times (mutazawwij arba), and leave the impossible burden of educating up to fifty children to their wives, being both culturally and economically unable to do so themselves. Sometimes they desert their families; when they do not, domestic violence is not rare, and the children tend to live down in the street, coming back home only to eat and to sleep. When the parents are living far away in the steppes (up to 1,200 km away from Riyadh), adolescents and young men who 'came up' to Riyadh for their studies rely on themselves or on some relatives. The discipline required by the university is undermined by the conditions of their lives. It can also depend on moral disposition and cultural capital more than on economic well-being: in the same extended family, for instance, young men in one branch, who are under the protection of educated and strong women, may graduate, while in another branch, wealthier but managed by uneducated men, children will be abandoned once they arrive in Riyadh and will tend to slip into delinquency, giving up studying after several failures and ultimately heading to the street, tafhit, and drugs. 


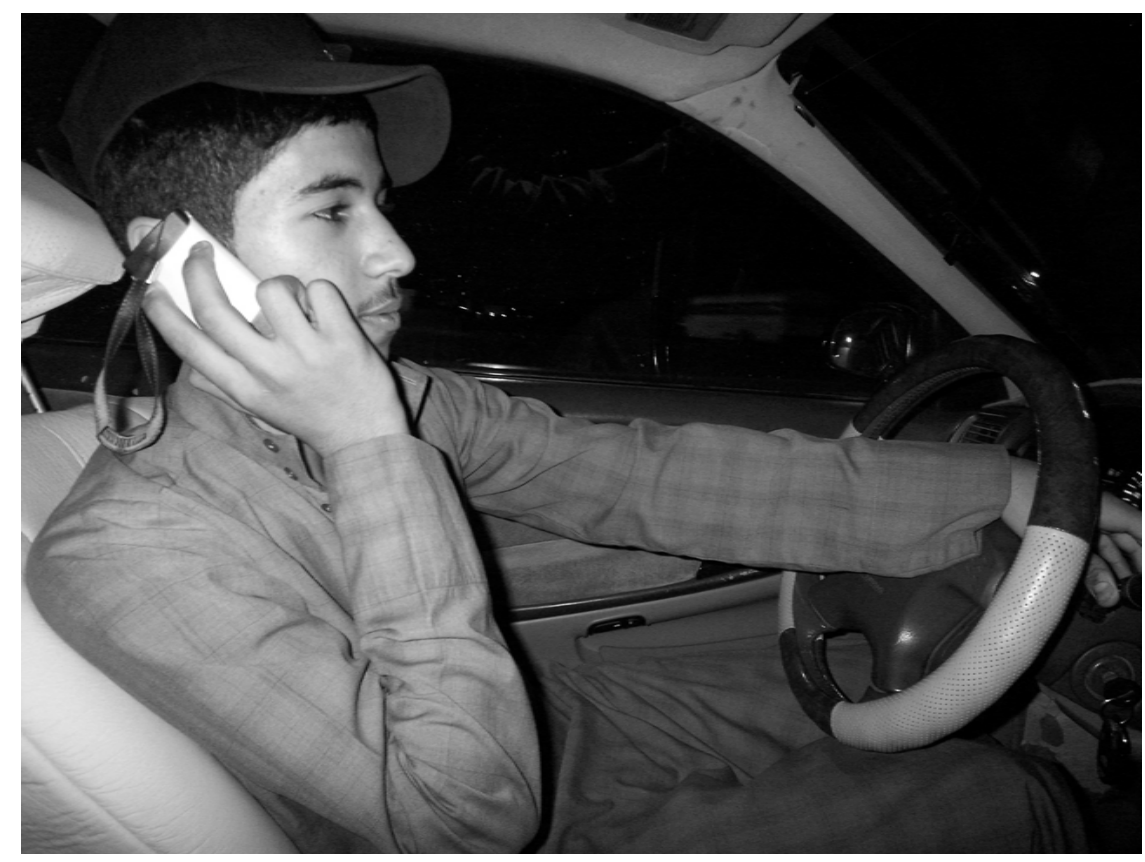

Fig. 2: A mufahhat wearing a thub and a baseball cap. (Photo: Pascal Ménoret)

The second kind of marginalization is cultural. With the foundation of the modern Saudi state in 1932, bedouins lost their traditional political and cultural preponderance (Pouillon and Mauger 1995). To be a bedouin today means sharing a stigmatized heritage and risking being misunderstood, or even feared, by members of the higher social classes, i.e. the descendants of oasis dwellers, now middle- and upper-class civil servants and businessmen. The bedouin dialects, although perceived as appropriate for poetry, are despised in everyday life as violent, rural, and rather primitive idioms. Clothing and physical appearance is another arena in which young bedouins are despised by sedentary society: 'Their aspect is frightening; they look like crap, as if they came out from under the earth, with their standing hair and their moustaches'. With their tight white clothes (thub) and the thousand ways they fold their headdresses (shmagh) or mix Arabic costume with Western accessories (such as baseball caps), young bedouins are clearly recognizable. Even though their clothing style has been imitated by most middle-class adolescents, it remains stigmatized by mainstream society. Young bedouins either frighten the sedentary people or are mocked by them for their supposedly inborn ignorance, anarchy, and violence. Old stereotypes provide a huge repertoire for insults and vexations. Tafhit thus is a hopeless rebellion against both the settled way of life and the Saudi norms. An anonymous poem says:

Go fast, burn tires! Cars make you the 'Antar of this time For your time has betrayed you The beautiful boys applaud you and prove your value The cop beats you No wonder he insults you, humiliates you 
Since you failed in everything

Nothing better your position

You left school and roam with bad boys

You did not hear your father when he cried because of you

Nor your mother when she shouted and exhorted you

You neglected her, you turned your back and you wanted her humiliation

Go, disappear and let your Lord resolve your crises

Go fast, burn tires until your ears explode.

Besides having written one of the Mu'allaqat, the pre-Islamic bedouin warrior and poet 'Antar is famous for his hostility to the sedentary Banu Tamim tribe, which is today one of the pillars of the modern Saudi state. 'Antar may be viewed as a role model by rebellious young bedouins; they nevertheless know that they have been 'betrayed', and that only their Lord can 'resolve their crises'. No salvation is to come from society. Economic and cultural marginalization is the fuel of a genuine social and spatial violence. Because of their aspect and behaviour, young bedouins are systematically expelled from most public spaces, malls, and other recreational facilities. Mostly left to themselves, they are utterly vulnerable to the police, the religious police, and the private security companies. Their social capital is clearly at stake: while young middle-class men can avoid the police thanks to their parents' relations (wasta), young bedouins are always at risk of having to spend several nights in the police station and endure bad treatment and beatings for having hung out at the wrong place and with the wrong person. As a result, they do not easily 'go down' to the bourgeois central neighbourhoods of Riyadh, such as 'Ulaya and Sulaymaniyya. They sometimes justify their fear of being socially despised by repeating the elders' position on those 'places of moral perdition'. The 'fine neighbourhoods' that reject them are thus one of the most popular goals of tafhit:

Play the horn. Skid and disturb the fine neighbourhood o Bûbû!

Let the patrols die of disgust and let them give up the chase, give up!

\section{Becoming a skidder: the street, the school, and the feeling of deprivation}

In the peripheral neighbourhoods of Riyadh, the 'hall of fame' is the street, where teenagers drive the family car very early, notably because of the prohibition on women driving. As the city is built around use of the car, with a poor public transport system that does not include the periphery of Riyadh, the individual vehicle is both the main condition of freedom of movement and a marker of the social identity of its driver: 'If you have a Lexus, you are yourself a Lexus. If you have a piece of shit, you are a piece of shit.' Furthermore, the configuration of the urban space facilitates risk taking, and straight, long desert highways allow young men to learn acrobatic driving. The openness of urban space is linked with the aggressive strategies of both real-estate investors (since the 1973 oil boom the real-estate market has been the major channel of rent distribution) (Bonnenfant 1982) and car importers, as well as the municipal regulations that require the opening of avenues and connection of electricity before the commercialization of any project. Real-estate development projects (al-mukhattatat) 
have become central in the lives of peripheral residents, who gather, play cards, have dinner, drink alcohol, or take drugs on the vacant lots, while the desert avenues are the skidders' playground. The real-estate boom and the unregulated importation of cars have thus provided the very infrastructures that allowed hajwala to thrive. The internet author of a history of hooliganism in Saudi Arabia puts it boldly: 'By the way, they [skidders] don't want to hear about the stock market boom. Why? Because when the share prices go up, the real-estate market stops or slows down. And if real-estate slows down, projects (al-mukhattatat) are stopped and with them the opening of new avenues ... You know how the story ends...'

Most parents who retain some authority over their children lock them up at home when they become aware of the modes of deviant socialization in the street. But such youngsters will often join a tafhit group during school days. The first step in the world of tafhit seems harmless, and consists of accepting from an older schoolmate a master key that will be used to 'borrow' a car. This simple means of admission, added to the excitement of penetrating a new world based on heroism and rebellion, makes it extremely difficult to resist the temptation of tafhit in the school environment. Neither the educational institution itself nor the preaching groups that attract young pupils through the organization of soccer tournaments and other playful activities (Ménoret 2005) can challenge the prestige of tafhit. 'We were all obsessed by it: you had to become a skidder!' says a ninth grader in a southern Riyadh high school before adding:
A: I feel like . . 1 per cent of the people are destined for the preaching group.... As for tafhit groups, they are larger. At the beginning of intermediary school, they distribute master keys to the pupils, those keys we use to steal cars. I remember this one day, I was walking back home and I saw two pupils, fresh ones, they were saying that they were about to steal a car, they had a key. That's their way of recruitment: they distribute keys to the pupils. And they gather important groups.
B: And entering tafhit is easier than joining a preaching group. I mean that you are watching them from your window, maybe you're gonna get down in the street and there, in front of the door, you'll find a guy, you'll chat with him, and this guy, maybe, he will let you in his car tomorrow. It's easier!

The master key is a challenge to the pupil; if he accepts it, he goes on to other tafhit-linked deviances. Should he decline it, he would immediately be confined to a subordinate position in his peer group. From the first step onward, a series of tests leads to the constitution of clear hierarchies inside the group, where dominant positions are the product of a consensus. The attractiveness of tafhit groups is all the more difficult to fight because they use extremely efficient media, from flyers to pagers and the internet, the mobile phone and Bluetooth.

The ease of entry does not by itself explain the 'fall into tafhit' and the formation of what one might call genuine 'deviant careers' (Becker 1963: 24 ff.). In such a repressive society, how can the individual manage to steal a car and join a group of drug addicts, when both crimes are supposed to be heavily repressed by the state? Young pretenders 
to the status of skidder provide many justifications for their acts: some talk of blind necessity ('We have only streets and cars, what do you want us to do?'), while others tend to minimize robbery ('We did not actually steal the car; we only borrowed it'). Others will glorify this first step and build a narration of injustice and revenge. These justifications are but $a$ posteriori rationalizing. and do not explain what happens during the initial risk taking. The violence of the immediate environment might well explain how young bedouin boys are driven into deviance. A famous preacher and former mufahhat tells the story of Abu Hasan, 'former hooligan and drug-addict', whose deviant career began when he was expelled from school for having stolen a sandwich: having experienced at a very young age the falaqa (bastinado) torture for an obviously tiny misdeed, Abu Hasan would later declare that 'the school was the beginning of perdition'. Domestic and school violence might thus explain many deviances. However, they do not enlighten the subjective state of mind of young people labelled 'deviant'.

Exploring the main feeling expressed by young bedouin men in Riyadh may provide a clue. When asked about tafhit, young men are unanimous: 'It is because of tufush', a colloquial Saudi word psychologists and sociologists translate by the classical terms 'boredom' (malal) (as-Sayf 1996: 107) or 'vacuum' (faragh) (ash-Shithri 2001: 170). These translations can be misleading, for tufush is more a social than a psychological disorder. Tufush is derived from a colloquial verb that denotes the random movements of a drowning man. Being tufshan is therefore not only experiencing a 'loss of future' (Bourdieu 1997: 336) or being disappointed or even disgusted by one's own living conditions, but also desperately trying to overcome this experience. While 'boredom (malal) is a mere emptiness, a big nothing', tufush is a feeling that 'drives you to do anything and everything, that drives you into being an 'arbaji [hooligan]', i.e. 'to sell the entire world for a bicycle wheel's price' or 'to take the whole world as a butt and to step on it'. Tufush might be analysed as the awareness of the discrepancy between subjective hopes and objective opportunities (Bourdieu 1997: 336), as the feeling of deprivation that results from the odd discovery that the economic and social opportunities Riyadh offers do not improve the young bedouin's social and economic condition. Shortly put, tufush is the feeling of being deprived of social or relational capital in a city where all opportunities - especially the economic ones - are within reach, provided that one gets the appropriate 'connection' (wasta). It is the rage that overwhelms young bedouins when they discover the essential inequality of the structure of opportunities - an inequality that contradicts the official 'developmentalist' discourse of the Saudi welfare state.

\section{The body capital}

The police, the Islamic preachers, and the schoolteachers judge tafhit as being tahawwur wa' 'abath (temerity and nonsense); even young middle-class men share this axiological point of view. It is clearly expressed by a young drag-racing aficionado, who compares his well-off and organized friends with the skidders: 'Us, we have goals, we know what we are doing. Our races are 70 per cent safe. Them, they are acting like fools, it is rabble 
(hamajiyya) and accidents.' Yet tafhit is not as confused and anarchic as it first may seem. It is a true discipline that requires of the individual the development of specific skills. A good skidder does not drink, does not smoke, and is dedicated to his excellence as an extreme driver. This ethics of self-control explains why Badr 'Awadh, nicknamed 'al-King', has been the unchallenged hero of tafhit in Riyadh for 16 years, while other less careful skidders have been seriously wounded or have even died. This ethics is sometimes justified in very mundane words and in references to the young boys that the skidder aims at charming:

For example, you are working for a company in which there is an outstanding employee. Of course, you want to be better than him. It is the same in tafhit. There is the love of younger boys (al-wir'anjiyya). But it is a kind of extra reward you get only if you become the best employee. If you enter tafhit for the boys' eyes, you will be bad in tafhit and lose the boys. You have to get into tafhit for tafhit's sake. You have to become the best one, because boys love excellence and dedication.

What is at stake here is an elaboration of a certain type of excellence or capital, the body capital, through the instillation of specific 'techniques of the body' (Mauss 1967: 51). The body is a main player in the world of tafhit - as well as in marginalized neighbourhoods in Europe or the United States, where the frequentation of gyms and fight-clubs and demonstrations of sheer violence are viewed as a valuable investment. An extreme kind of body capital is thus the 'warrior capital' (capital guerrier) that is required in particularly violent environments, such as some American barrios or French banlieues (Bourgois 1996: 22-8; Sauvadet 2006: 95-105) and whose main features are 'courage, elegance, mastery, and reputation' (Sauvadet 2006: 99).

Saudi Arabia is characterized by an intense concentration of the various legitimate species of capitals. The political capital (Bourdieu 1994) is monopolized by certain branches of the royal family. The economic capital - which might be seen as an appendix of the political capital - is monopolized by some princes and by their entourage of businessmen and traders. The legitimate cultural capital, although a thin portion of it has been granted to a secular intelligentsia, is almost totally in the hands of the religious elite and has become - because of the limitation of the political capital - the object of intense competition between various pretenders, including the traditional elite of 'ulama and preachers, the new counter-elite of the Islamic awakening (as-sahwa al-islamiyya), and, more recently, the jihadist movement (Al-Rasheed 2007). Due to the authoritarian seizure of the political and economic capital, the cultural capital is the only legitimate capital open to newcomers, who may acquire it at the university or, more frequently, through membership of an Islamic group, whether pro-government or of a more oppositional nature, the religious field being the only one not to be subjected to a strict reproduction pattern. The people we are studying here have been excluded early from the education system, and belong to this majority of young Saudis who either never entered the education system or drop out of school before completing their secondary 
or higher education (Prokop 2003: 87). As such they are not only excluded from the political and economic capital. Unless they adopt the asceticism and the peculiar codes of the Islamic groups, they are also deprived of any possibility of acquiring cultural capital. Our hypothesis is that the body capital is the only capital that remains when all other opportunities have been monopolized by specific fragments of society and when no economic, social, or cultural feature of the individual is convertible into social respect, and thus symbolic or real profits.

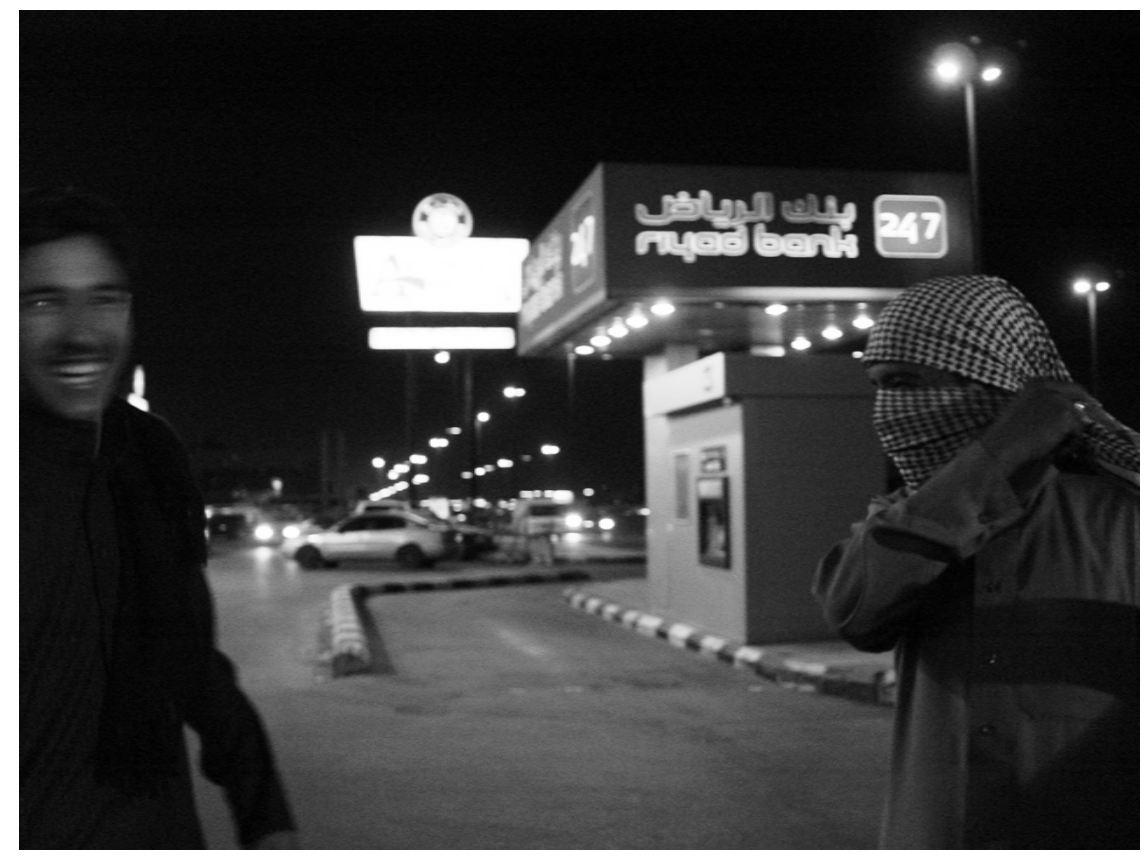

Fig. 3: Two skidders on a main avenue of Riyadh. For security and symbolic reasons, skidders cover their faces with their shmagh, just like jihadists do. (Photo: Pascal Ménoret)

Holding another type of convertible capital, such as cultural Islamic capital, does not mean that the body capital is not invested. Various body techniques are at stake inside the Saudi religious establishment itself, whose insistence on the multiple details of ritual purification is well known. Young Islamists shorten their clothes and grow their facial hair: they expect these measures to gain them the respect society refuses to the young people. Al-Qaeda in Saudi Arabia is also investing the body as both a weapon and a place of resistance (Al-Rasheed 2007: 156-63). As for young bedouins, the care of the body will first of all accentuate the stigma: the unusual way of wearing shmagh (headdress, see fig. 3), as well as the mixture of Saudi dress and Western accessories, are aimed at subverting the refined dress codes of upper Saudi society. Second, the body has to be adjusted to the machine through various exercises in order to confront the risk and the possibility of death. A famous (now closed) tafhit website used to propose online training under the slogans: 'at-Tadris li-'uyun zahif ma hi khasara' (learning for a mufahhat's eyes is not a loss) and 'al-Funun junun' (madness is an art). Finally, the body 
is constituted as a weapon: like al-Qaeda supporters (Al-Rasheed 2007: 156), mufahhats are stressing the importance of being thin in a society where obesity is widespread. 'Ezhef, tanhaf!' (crawl, do tafhit, you will get thinner), reads a tafhit slogan. By its ability to confront death and to distinguish itself from the dominant codes, the body of the mufahhat is glorified and allows him to become a hero. The reinterpretations of the common dress code as well as the proclaimed deviant sexual behaviour and the ability to put one's physical integrity at stake in the 'urban jungle' are nothing but symptoms of a rebellion of the body against the dominant norms of Saudi society.

\section{Avenues of participation}

The discipline of tafhit does not concern only the body. Skidders have also elaborated specific group techniques in order to counter official tactics of repression. A typical tafhit session is organized by the fans (al-mushajji 'in) themselves, who during the afternoon beg a skidder to 'throw the iron' (siff al-hadid) or 'domesticate the steel' (ta'dib al-hadid). Fans usually gather money to pay him, while the skidder's 'attendants' (ta'ziz), the ones who will ultimately sit in the hero's car, entrust younger members of the network with stealing some cars. Then a central figure, the 'orienteer' (muajjih), organizes the night, mobilizing his networks and gathering the largest possible number of spectators in carefully selected places, both well known amongst the tafhit fans and relatively new in order to avoid discovery. He also contacts other skidders and manages to organize an attractive panel by choosing both the best places and the most dedicated heroes. The skidders finally head towards the first 'spot', every one of them accompanied by his fans, two or three improvised ambulances driven by the 'supporters' (musanidin) in case of an accident, and a crowd of cars, constituted in procession (mawkib) and moving very rapidly along the large avenues of Riyadh. In every spot, skidders do several 'shots' (shut) of combined figures, while the fans pack the sidewalk, filming, taking pictures, or simply watching. After the show, everyone quickly gets in his car for fear of the police patrols and moves to another spot. These gatherings, which can involve more than fifty cars, usually take place during school exams, holidays, and the month of Ramadan. The golden hour is at dawn, after the fajr prayer, between patrols. The most delicate operation is to prevent discovery. This is the task of the 'radar' (radar), whose goal it is to gather and update data about the strategies of the police forces, and to inform the 'orienteer', who will react accordingly, either moving the procession from one spot to another or even cancelling the show when danger is at hand.

The hierarchy of tafhit is essentially an adaptation to the techniques of surveillance and repression of the Riyadh police. The chaos of a moving procession is in fact the result of meticulous organization and coordination. The appearance of disorder and extreme speed are tactics elaborated against the partitioning and monitoring of an urban area that has become an 'analytical' and 'disciplinary' space, i.e. a space that 'cancels the effects of indecisive repartitions, the uncontrollable disappearance of individuals, their diffuse circulation, their unusable and dangerous coagulation', a space that 'institutes useful communications and interrupts any other form of movement' (Foucault 1975: 
168). Speed is the only way of escaping the surveillance of the urban space and its visibility: the large avenues of Riyadh, accessible only by car and monitored by video cameras, hinder the formation of any mass meeting. The 'analytical space' of Riyadh splits up individuals by its very configuration and the many possibilities it offers to the police, so that mass demonstrations on foot are nearly impossible. Only the gathering of numerous cars speeding along the street can allow protesting individuals to escape repression. This method of dissent is embedded in the very 'spatial routines' of the daily life 'that bring large numbers of people together in particular places' (Sewell 2001: 62), these places in Riyadh being cars and highways - moving places - rather than squares or sidewalks. Some techniques familiar to urban walking rioters are used by young drivers, such as the 'swarm' tactics observed during the 1990 revolution in Nepal (Routledge 1997: 76). It consists of a sudden gathering of people at strategic locations, followed by their dispersion when police forces arrive. Many diversion tactics are also used, such as the organization of up to two or three fake parallel tafhit shows that mislead the police patrols. In this case, tafhit fans don't disperse but force the police to do so.

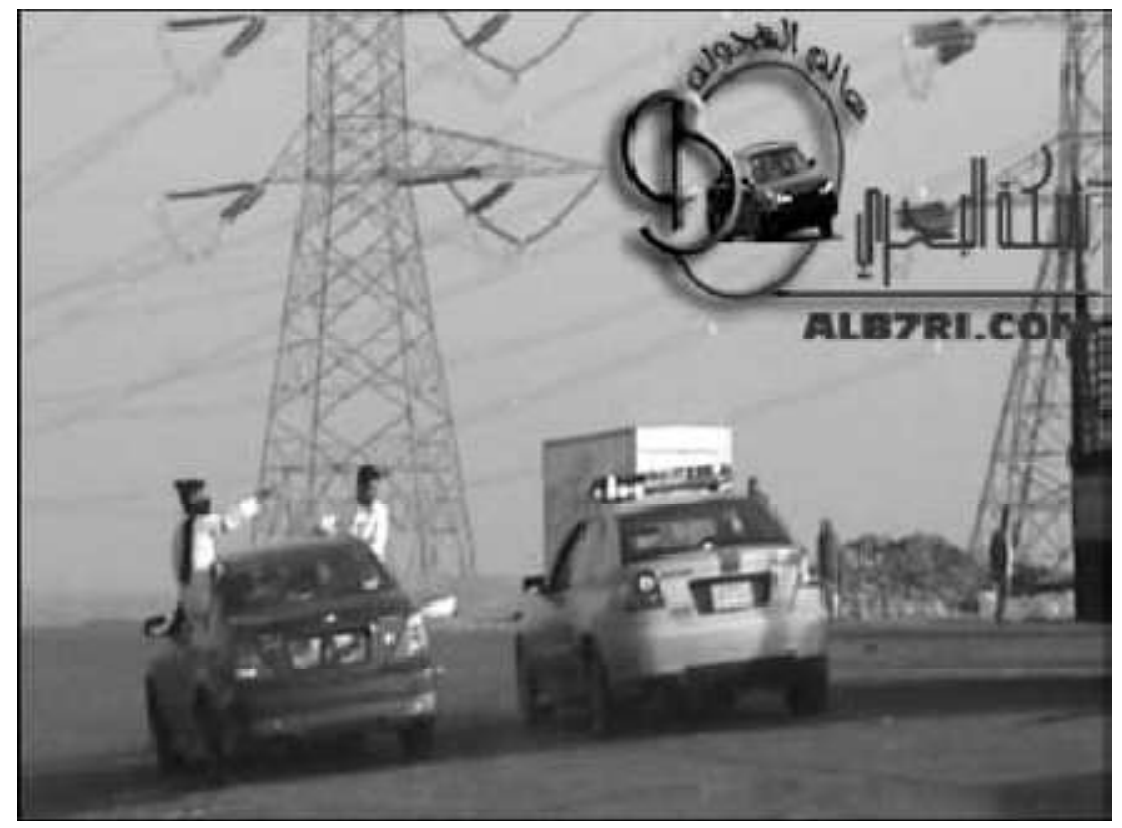

Fig. 4: Defying the police. A famous tafhit's slogan reads: 'Skid, get drunk and forget the cops' (Fahhet, eskar w-ensa al-'askar). (Source: www.alb7ri.com)

Space is not only the site of mobilization. Nor is it only its object: it is also an effective cause of the mobilization itself. Tafhit 'gives you the sense of time and space', and space in return gives tafhit its very signification. As does repression: the confrontation between police forces and young people tend to politicize and organize small-scale or low-intensity dispersed movements (Bayat 1997: 8). The complex pyramidal organization of tafhit groups, from 'fans' to 'supporters' to 'attendants', 'radar', 'orienteer', and the skidder himself, is aimed at challenging the various techniques of the police, the most 
feared of which is the 'web' (shabaka) technique, which consists of blocking a whole neighbourhood, tightening the trap, and eventually picking up both the skidders and their fans. The organization's goals are: gathering fans and controlling their movements; watching the police and avoiding arrest; and protecting the skidder in case of massive breakdown. Attracting fans thus bears a double signification and aims at both satisfying a demanding public and potentially hiding the hero in the moving crowd. Protest and resistance are tightly linked. If the police are feared for their repressive tactics, they are also the goal of many provocations, such as throwing insults ('try to follow me, you fag' or 'hey beautiful, do you wanna get in for a ride?'), eggs, and stones at a police patrol. At some points, retaliation may follow an aggressive police operation: in an eastern neighbourhood of Riyadh, the police station was once robbed and ransacked on the eve of its inauguration by the amir of the capital (head of the local administration). Organization is a response to repression; it may also be the backbone of authentic though limited protest actions against the very structures of local power.

\section{Urban unrest and non-ideological radicalization}

That the peripheral neighbourhoods of Riyadh are first and foremost playgrounds for turbulent children who ride cars in a crazy manner may sound good for the antiterrorist planners, for whom the south and east of the capital have seemed havens for young terrorists and Islamic extremists. The south of Riyadh notably has a pretty bad reputation and is still nicknamed 'the Falluja of Riyadh' or the 'Sunni triangle' for its supposedly peculiar ecology of activism and rebellion. Yet for Riyadh's youth, rebellion's theatre is first of all on the streets. Along the lines of the ancient hatred towards bedouins and the renewed marginalization of young people coming from low-class and rural backgrounds, tafhit plays anew the old narrative of bedouins vs. oasis-dwellers. Reviving the moral codes and values of bedouin society, chanting their exploits in poems and songs, risking their lives for the attention of their beloved ones, young skidders imagine themselves as errant heroes of the Saudi urban post-modernity. They attract by their words and deeds far more supporters than the Islamic groups can do with their ascetic conception of the self and their rigid way of painting life. Like the low-riding sub-culture of Los Angeles, tafhit groups offer "cool worlds" of urban socialization for poor young newcomers' from rural areas (Davis 1992: 293), beyond the narrow circle of the family and against the official norms propagated by such local institutions as the school and the mosque. It might be misleading, however, to abruptly oppose 'deviant' and 'Islamic' socializations as two separate poles of attraction. In reality, the politics of deviance has often been an introduction to more organized and effective politics of (Islamic) defiance.

The history of the relations between tafhit and Islamic groups is indeed all but a simple one. Like the Saudi Islamic movements, tafhit made its first appearance during the 1970s. They have both invested the same spaces: the neighbourhood (al-hara) and the school. They both aim at recruiting the largest possible number of members and have launched many propaganda campaigns, using more or less the same media: first the 
flyer, then the pager, and finally the mobile phone and the internet. The overwhelming success of tafhit's songs, the famous kasrat that glorify hooliganism and the street heroes, may be compared with the revival of Islamic hymns (anashid), despite the Salafi prohibition of music: this very space also was an arena of competition. Tafhit has the obvious advantage of being not only 'cooler' than Islamic socialization, it also addresses more directly the current and immediate problems of the time. It is a rebellion against the very structures of consumption and economic power, while the Islamic movements, in order to reach the same goal, are taking a long detour through religious revival and moralization of the social life. Since the oil boom of 1973, the real-estate market and the monopolies on vehicle sales are two main pillars of enrichment for the royal family's entourage. These very visible elements of power are the first targets of skidders, through the multiple strategies we have been analysing here. The hatred of the 'big shots' that control the Saudi economy of consumption - and thus the Western interests that they are supposedly supporting - is unveiled in the discourse of many tafhit fans: 'It is with our oil that you [the West] make cars. And you sell them back to us at top prices. And us, we destroy them.' 'It is a Zionist and American plot. They import cars to destroy us.' 'Rich guys provide us cars and play on us.' The real-estate development projects are also targeted as being the 'killer of youngsters'.

Such longevity in low-intensity rebellion, experienced week after week and season after season in various parts of Riyadh, discovering new playgrounds and spaces, following up the city's astonishing boom and conquering new modes of expression, is rather unusual and tends to contradict the principle according to which 'insurgency is always short-lived' (Piven and Cloward 1977: xxi). This rebellion indeed was not only fuelled by the continuous explosion of real-estate speculation and by the acceleration of the country's heavy dependence on the outside producing world, It was also at the crossroads between two intertwined phenomena. Eager to undermine the first political opposition of the Islamic movements, the Saudi government launched in the 1980s a 'crusade against Evil' and a campaign to enhance the 'moral order' of the society. This interpretation of political protest as mere moral and cultural grievances was to become the first and more effective de-politicizing tool of the Saudi state, and was about to radically alter the everyday life of Saudis. Old habits became new deviances; the very notion of public space disappeared almost totally; the economic strategies of the royals and their entourage were hidden behind religious protestations. At the same time, the rising level of corruption and the poorly mastered public expenditures allowed imported goods, the most famous of them being weapons and cars, to flood the country.

Radicalization without an ideology, tafhit is one possible self-destructive response to radical socio-economic conditions. The deviant careers of well-known or more obscure skidders can end up in religious involvement and repentance, or even lead them to violent experiences. One particular group of skidders who were operating in the northeast of Riyadh in the middle of the 1990s is emblematic of these chaotic journeys. Out of ten skidders, two died in tafhit accidents; two others are in jail; one has repented 
and become pious after having killed a man during a tafhit accident and having been jailed for several years; two joined the Tabligh movement and preach in the western province of the country. Three of them joined activist groups after a short period of preparation (two to four months) and now fight with the Iraqi resistance. The previous generation of skidders had had the same experience, this time in Afghanistan where 'the story of hooliganism ended up', some of the bolder youngsters of Riyadh heading eastwards to fight the Red Army. From the rebellion of the body against the Saudi codes and monopolies to a rebellion of the body against the 'New World Order', this non-ideological radicalization shows that sometimes suicide fighters do not need to be 'born-again Muslim' in order to participate in a defensive jihad: 'The articulate minorities ... arise from a less articulate majority whose consciousness may be described as being, at this time, "sub-political"' (Thompson 1963 59). This less articulate majority, through its tactics of resistance and protest, is training itself to the very gestures of war, and might turn the 'body capital' into an authentic 'warrior capital'. In extreme circumstances, the body may be turned into a weapon, as a means for the individual to achieve his individual fate, to prepare the way for the Islamic state - or general anarchy. 